\title{
Assessment of the Role of Greenbelts in Environmental and Socio-Economic Development of Urban Areas in Southeast Nigeria
}

\author{
Nicholas I. Obi ${ }^{*}$, Dickson M. Nwalusi, Eziyi O. Ibem, Ogochukwu F. Okeke \\ Department of Architecture, University of Nigeria, Enugu Campus, Enugu State, Nigeria
}

Received January 27, 2021; Revised February 26, 2021; Accepted March 30, 2021

\section{Cite This Paper in the following Citation Styles}

(a): [1] Nicholas I. Obi, Dickson M. Nwalusi, Eziyi O. Ibem, Ogochukwu F. Okeke, "Assessment of the Role of Greenbelts in Environmental and Socio-Economic Development of Urban Areas in Southeast Nigeria," Civil Engineering and Architecture, Vol. 9, No. 2, pp. 545-557, 2021. DOI: 10.13189/cea.2021.090227.

(b): Nicholas I. Obi, Dickson M. Nwalusi, Eziyi O. Ibem, Ogochukwu F. Okeke (2021). Assessment of the Role of Greenbelts in Environmental and Socio-Economic Development of Urban Areas in Southeast Nigeria. Civil Engineering and Architecture, 9(2), 545-557. DOI: 10.13189/cea.2021.090227.

Copyright $\mathrm{C} 2021$ by authors, all rights reserved. Authors agree that this article remains permanently open access under the terms of the Creative Commons Attribution License 4.0 International License

\begin{abstract}
As urban areas in many developing countries continue to witness rapid spatial and demographic growth, the sustenance of greenbelts is seriously threatened due to increasing demand for land for housing and provision of urban infrastructure. However, in a country like Nigeria, there is a lack of clarity on some contentious issues regarding urban greenbelts. This study investigated the role of greenbelts in environment and socio-economic development of cities in southeastern Nigeria. A questionnaire survey of 300 built environment professionals, including architects, engineers, town planners, land surveyors, quantity surveyors and property developers was conducted in the study area. The data were analysed using descriptive statistics and Chi-square tests of significance and it was observed that although around $75.3 \%$ of the respondents agreed that green belts contribute to increasing pressure on the existing land in the study area; most of the participants indicated that greenbelts play significant role in urban environment sustainability and socio-economic development by protecting air and water, serving as local sources of food and medicine, means of preserving agricultural land, promoting biodiversity and preventing urban land degradation. In addition, prohibiting housing and physical developments in greenbelts and using Brownfields as alternative sources of land for housing were identified as the possible strategies for preserving urban greenbelts in the study area. This research is intrusive in revealing the key roles greenbelts play in urban
\end{abstract}

development agenda and the possible ways for preserving them in rapidly urbanizing regions in Nigeria and beyond.

Keywords Greenbelts, Housing Development, Rapid Urbanization, Sustainability Agenda, Urban Areas

\section{Introduction}

One of the ways urbanization manifests in many countries in the global South is rapid transformation of semi-natural and natural ecosystems to built-up areas leading to a massive loss of biodiversity. Before now, most urban areas in Nigeria were of manageable sizes with easy access to farmlands or countryside but in cities such as Lagos, Kano, Port Harcourt, Enugu and others with huge and rapidly growing population $[1,2]$, open fields and green belts are fast disappearing due to rapid spatial growth of these cities. Some authors $[3,4]$ have noted that rapid urbanization coupled with unplanned and unabated incursion into green belts and depletion of natural landscape elements have exposed Nigerian towns and cities to serious environmental sustainability challenges. This view was corroborated by Daramola and Ibem [5] who also observed that rapid population growth accounts for the fast rate of spatial growth of urban areas leading to the proliferation of urban slums and 
uncontrollable depletion of greenbelts in many cities in Nigeria. This development is of course not limited to Nigeria alone but also extends to other countries. For example, Gospodini and Manika [6] reported that large cities in Greece have also been experiencing rapid and under-regulated spatial expansion, characterized by informal housing in urban periphery leading to a significant reduction in natural habitats, including greenbelts.

Evidence in the literature $[5,7]$ also suggests that poor planning and high intensity of urban land use have contributed to exacerbating environmental challenges in most Nigerian cities. Research has identified one aspect of land use in urban areas in Nigeria to be continuous conversion of greenbelts and open spaces to buildings and other physical infrastructure [8]. In fact, previous authors $[9,10]$ have revealed that the continuous expansion of cities and conversion of hitherto virgin landscapes to built-up areas as major factors that trigger and speed up the rate of loss of biodiversity and ecosystem imbalance leading to environmental degradation. Studies in a country like China have also identified the negative impact of urban expansion on air quality, food production, soil conservation and water purification $[11,12]$. In addition, it has also been reported that reduction and loss of urban vegetation also affect the adaptation of urban areas to climate change [13] and that densely built-up and scarcely vegetated areas are more prone to climate change related challenges than suburban and sparsely built-up ones [14].

The idea of preservation or use of greenbelts originating from Ebenezer Howard's 1898 conception of Britain's "Garden City", where he used greenbelts to separate residential from industrial areas. Arising from this, greenbelts have been described as areas comprising largely of undeveloped, wild, or agricultural land within or around urban areas that prevent the outward sprawl of spatial development [15-17]. Consequently, some authors have identified several benefits of greenbelts in urban areas to include air pollution control and storm water runoff reduction, building energy savings $[18,19]$, reduction of carbon emissions $[20,21]$ and carbon dioxide sequestration $[22,23]$. These studies underscore the environmental, social and economic benefits of greenbelts within and around urban areas.

In Nigeria, previous studies have identified the benefits of greenbelts to include space for relaxation, leisure and recreation [24], provision of medicinal and ethno- botanic resource and food tree species [25] as well as for socio-cultural to religious, commercial and even agricultural activities [26]. In spite of these, the growing demands for housing and other physical infrastructure have continued to exert enormous pressure on the existing greenbelts, forest reserves and agricultural lands in many Nigerian cities. In fact, Ladan [27] reported that in several developing countries, maintaining green belts areas has been a very difficult and challenging task due to the pressure on existing land for housing and provision of basic infrastructure. In a city like Owerri, southeast Nigeria, the Christian Voice Online [28] reported that before government interventions, greenbelts around this city had been occupied by illegal structures. In the face of these challenges, some authors have argued that the practice of having green belts in cities should no longer be condoned as they tend to reduce the quantity of developable land which partly leads to both the scarcity and high costs of land and housing [29,30]. In support of this, Barker [31] also insists that the designation of greenbelts needs to be reviewed in order to relieve pressure on urban land.

In the midst of these arguments, some authors were of the view that the benefits of green belt were yet to be well articulated in the research literature to warrant their incorporation in the planning of towns and cities, especially, in rapidly urbanizing cities in sub-Saharan Africa [32-34]. It was on this premise that Amati [35] stressed the need to improve understanding of the relevance of green belts in the current urban development discourse in Nigeria. It was in response to this that the current study investigated the role of urban greenbelts in environmental and socio-economic development of four selected cities in southeast Nigeria with a view to making suggestions on how to preserve urban greenbelts in the study area. The specific objectives pursued in this study were to:

1. examine the perceptions of built environment professionals and private developers of the demerits of green belts in four selected cities in southeast Nigeria,

2. assess the role urban greenbelts in environment and socio-economic development of the selected cities; and

3. identify the possible strategies for preserving urban greenbelts in the study area.

This research is considered valuable in identifying the demerits of urban green belts, their role in environmental and socio-economic developments of cities and the strategies for preserving them in the face of competing demand for urban land for housing and infrastructural development. It is expected that the findings of this research will inform policy and practice on the preservation and conservation of greenbelts in urban areas of Nigeria and other developing countries faced with the challenges of rapid depletion of natural habitats and massive loss of biodiversity.

\section{Context of Study}

Geographically, Southeast Nigeria is one of the six geopolitical zones in this country. The zone is made up of five States: Abia, Anambra, Ebonyi, Enugu and Imo as shown in Figure 1. 


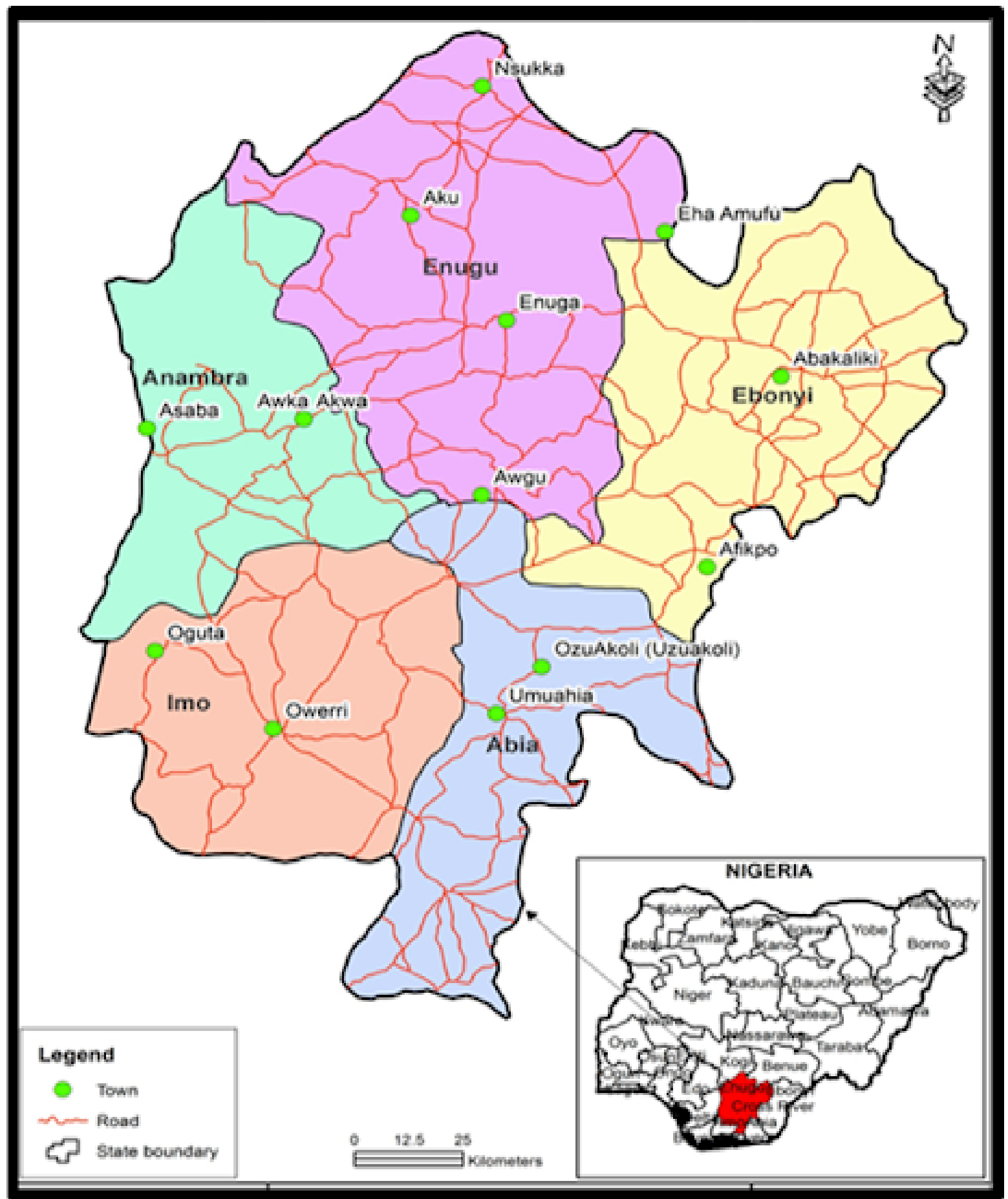

Source, Geographical Map of Nigeria (2020)

Figure 1. Map of South East Geopolitical Zone of Nigeria

This geopolitical zone lies within the rainforest belt of Nigeria and experiences two main seasons: the rainy season, which starts from April and ends in November and the dry season, which starts from December and ends in March. The average yearly rainfall ranges between $3000 \mathrm{~mm}$ and $4000 \mathrm{~mm}$, while the average values of yearly temperature are between $30.0^{\circ} \mathrm{C}$ and $36.0^{\circ} \mathrm{C}$ [36]. The 2006 national census showed that the population of the zone was $16,381,729$ people [2]. Based on $3 \%$ annual growth rate, the estimated population of the zone in 2019 was put at about 22,279,151people with an estimated population density of 766 persons $/ \mathrm{km}^{2}$. The study area comprised the capital cities of four States in the zone. These are Enugu, capital of Enugu State; Owerri, capital of Imo State; Abakaliki capital of Ebonyi State and Awka, the capital of Anambra State. These cities were 
purposively selected because they are the administrative capitals of their respective States and have evidence of greenbelts. For example, Enugu, has the following green belts, namely; Enugu Zoological Garden, Market garden, Ngwo field, Onwudiwe Park, Eze Park, Ejindu Park, Ekulu River banks, Nike Lake forest and Garden Park, Golf Garden, Ugwu Onyeama forest, Ugwu Udi Forests (see Figure 2), Ugwuaji forest, and others in different layouts and locations around the city.

Owerri has the following greenbelts Nekede Zoological Garden and Forestry (Figure 3), Nworie River and Otamiri River green belts stretching along the river banks, and Owerri Robber Plantations, while in Abakiliki, apart from the green belts at the city's boundaries, are notable greens areas along the River banks and Abakaliki Golf Club and Amusement Park. Similarly, Awka has greenbelts along the banks of Ebenebe River separating it from Enugu State extending into the border communities of Amasea and Ugwuoba. The initial green belt enclosing Awka urban has been punctured at different locations by fast growing communities such as Ebenebe, Enugwu Agidi, Isu-Alaocha, Okpuno and Nibo, which are around the city.
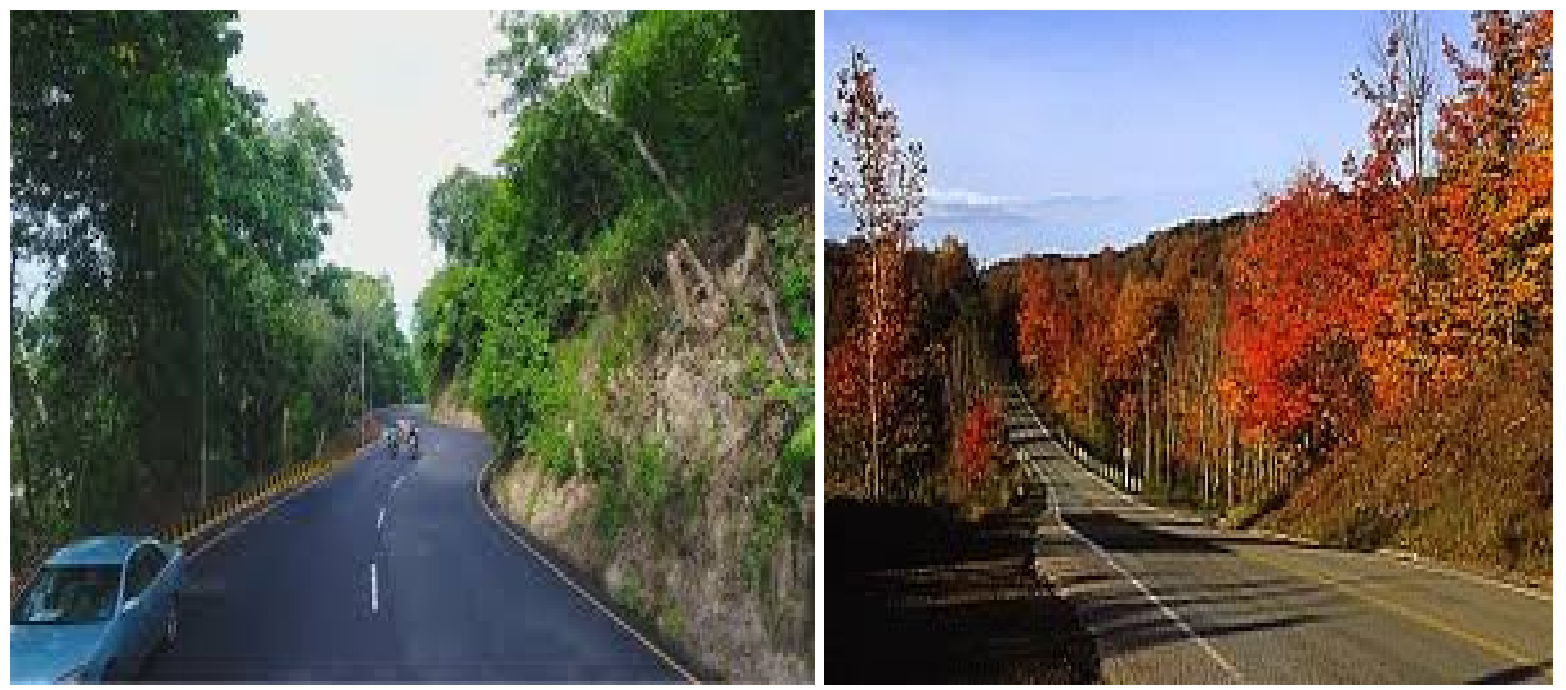

Source, Researcher's Fieldwork (2019)

Figure 2. Ugwu Udi Forests
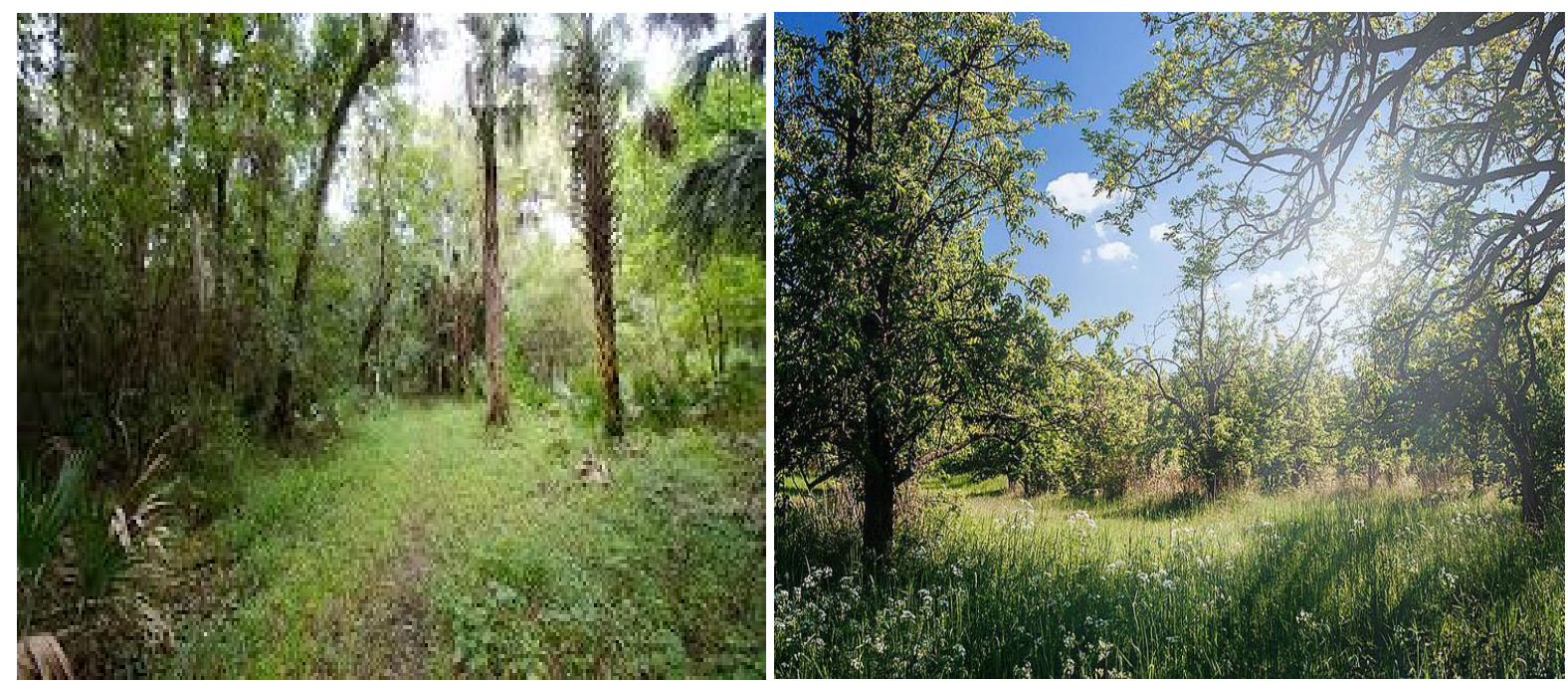

Source, Researcher's Fieldwork, 2019

Figure 3. Nekede Zoo garden and Forestry, Owerri 


\section{Literature Review}

\subsection{Concept of Urban Greenbelt}

Although the origin greenbelt has been linked to Ebenezer Howard in his design of what he called "Garden City" where he used greenbelt to separate residential development from industrial areas, some authors $[35,37]$ were of the view that green belt gained prominence via the early post-war modernist ideals that influenced planning in the UK between the 1940s and 1950s. Furthermore, the evolution of "garden cities" characterized by park belts, green girdles, parkways and green webs, green spaces, watershed, wetlands, agricultural land has been linked to greenbelt cities [38]. Nonetheless, Kuhn and Gailing [39] explained that the idea of having green spaces in cities became evident in cities like Berlin and Vienna during the late 19th and early 20th centuries. According to the proponents of greenbelts such as Ebenezer Howard, Raymond Urwin, Patrick Abercrombie, green belt represents area of land used to retain largely undeveloped, wild, or agricultural land around urban areas to prevent the outward sprawl of buildings and urban infrastructure [17]. In their study, Amati and Taylor [30] noted that the term 'green belt' has been part of the planning lexicon since the beginning of the 20th century and insisted that the establishment of greenbelt has now assumed international recognition. For examples, it was reported that in Japan and Korea, green belts were introduced to serve strategic and military purposes [40,41]. In addition, the concept of 'green infrastructure' which has been described as open spaces in urban settings designated as parks, forestry and playgrounds and green areas that link small gardens to green belts within urban landscape that serve several functions such as recreation, relaxation and social interactions came into prominence from urban green belt movement $[24,42]$.

Historical facts show that green belt emerged as a deliberate urban planning policy aimed at having natural vegetative areas and water bodies to contain sprawl and protect cities from social and environmental challenges associated with sprawling $[15,16]$. It is also known that greenbelt is a more permanent urban feature [43] and can be in the forms of linear parks or centric expanse of pastoral land of open space circling a city or town [38], green wedge, greenway and green web $[35,44]$ and reserve open land around urban areas $[35,45]$ that help to preserve open land around urban areas and limiting urban spatial growth [46]. In view of these, some authors have concluded that having greenbelts is a veritable approach urban planners and designers use to control rapid urban spatial growth and separate urban from rural areas [37].

In African cities, it was reported that indigenous people understood the concept of greenbelts as they created all kinds of public and private open spaces, ranging from the village greens, town squares, sacred gardens and squares to royal gardens [47]. This was corroborated by Abdulkarim [26] who also explained that the concept of greenbelt is seen in most indigenous African cities in the form of open and green spaces that serve socio-cultural, religious, commercial and agricultural functions. In the city of Kastina, northern Nigeria, it was observed that before now green belts stood outside the city wall, but these have disappeared as a result of infrastructure development and afforestation leading to denial of the city and its residents the numerous socio-economic and environmental benefits of the greenbelts [48]. In any case, the foregoing suggests that the idea of greenbelt has existed in urban areas in Africa even before the advent of Europeans. This means that the idea of having greenbelt may not be a recent development in countries in many African countries.

\subsection{Greenbelts and Urban Development Agenda}

Research has shown that the concept of greenbelt has influenced the design of urban landscape in many cities in Europe, America and Asia [40,49]. Specifically, Abbot [50] reported that in 1977, Portland, Oregon, greenbelt was officially used in 1980 mainly to delineate the extent of urban development beyond which agriculture and natural conservation activities were encouraged. In India, it is also on record that the capital city- New Delhi and commercial centre of Mumbai and other cities had maintained green belts [51]. The reason for inclusion of green spaces in the design and planning of many cities are not farfetched as the literature is replete with studies on the environmental, social and economic benefits of greenbelts to cities and their inhabitants [6]. For examples, several authors have revealed that green belts in cities play diverse roles in promoting urban sustainability by enhancing the aesthetics of urban landscape [30,52]; providing space for relaxation [52,53], leisure and recreation [24]; and serving as watershed, wetlands and agricultural lands for food production [44]. They also help in curbing urban sprawl and urban amalgamation [54], serving as sources of medicinal plants and food trees [25,55]. Green belts are also known to protect natural areas, clean water, fresh air and wildlife, provide natural habitats for plants and animals [15], help in air pollution control and storm water management $[18-20,56]$; reduction in energy consumption in buildings [20,57]; and in carbon dioxide sequestration [23,58]. Further, greenbelts help to sustain small settlements [17], preserve agricultural land; and thus ensuring food security $[26,44,51]$ and provide habitats for endangered species [15].

In Nigeria, the Nigerian Urban and Regional Planning Decree No. 88 of 1992 has made provision for urban centers to have a good proportional of land use designated as open spaces from which recreation parks could be developed for leisure, physical exercises and 
social interactions, and for environmental sustainability. In line with this, it has been revealed that in Nigerian's Federal Capital Territory (FCT), Abuja, greenbelts in forms of parks and gardens such as Millennium Park, Abuja Zoological Park and Gardens, Orange Park and Gardens, National Children's Park and Zoo and others have been created for relaxation, recreation and improvement of the city's environmental sustainability status [53]. In Owerri, the existing greenbelts have also been identified as key sources of medicinal plants and food tree; and thus contributing to the health of the residents [25]. This finding seems to be in line with the situation in Ontario's Greenbelt where trees were reported to be very important to the residents as sources of food and medicinal plants [55]. Similarly, in Lagos, southwest Nigeria, some authors reported that urban green areas contributed to mitigating environmental sustainability challenges such as emission of greenhouse gases, poor waste management practices, and water pollution confronting the city [24] and also help to foster sense of community among residents the residents [42].

In spite of the benefits of urban green belts as previously highlighted, there are contentious issues on urban greenbelts, especially in the developing world. Among these, some authors have argued that the practice of incursion of physical developments in green belts was necessary to reduce housing scarcity $[3,4,27,49]$. This line of thinking is based on the notion that development within green belt helps to gain access to developable land [31], having greenbelts contributes to the high cost of housing $[29,30]$ and that housing development beyond green belt boundaries can serve as a means of reducing pressure on the existing urban land [17]. In contrast, other scholars are of the view that urban greenbelts should be sustained by making them permanent features of urban landscape [39] and taking deliberate steps to preserve them [51]. They also canvassed for the use of Brown fields as alternative sources of land for housing development and by having development around green belt boundaries instead of allowing developments within greenbelt areas [15].

It is evident from the existing studies reviewed here that the importance of greenbelts in the social, economic and environmental development of urban areas within and outside Nigeria is well noted by previous authors. However, except that study in Owerri by Adeyemi et al. [25] most of the existing studies on greenbelt in Nigeria are focused on urban areas outside the south-east geopolitical zone. It is also clear from the internal literature that there are two opposing views on the continuous inclusion of greenbelts in the planning and design of urban areas. However, it is not clear which part of the divide stakeholders in the built environment in major urban centers in southeast Nigeria belong to and the strategies for preserving urban greenbelts in this part of Nigeria. This is the gap the current study sought to address.

\section{Research Methods}

The study adopted survey research design and covered four main cities, namely Enugu, Owerri, Abakaliki and Awka in south-east geopolitical zone of Nigeria (see Figure1). The research population consists of architects, town planners, land surveyors, engineers, quantity surveyors and real estate developers in the aforementioned cities. The available records from the professional associations of the occupational groups mentioned indicated that their membership strength in the study area was 1200 persons. Consequently, in calculating the sample size for the survey, the formula for estimating sample size for a finite population developed by Yamane [59] and shown in equation 1 was used.

$$
\mathrm{n}=\frac{N}{1+N(e)^{2}}
$$

Where $\mathrm{n}$ is the calculated sample size, $\mathrm{N}=$ is the research population, e is allowable error in statistical estimation, which for this research is $\pm 5 \%$ margin of error at $95 \%$ confidence level. Substituting these parameters as shown in Equation 2, a minimum of 300 participants were obtained.

$$
\begin{gathered}
n=\frac{1200}{1+1200(0.05)^{2}} \\
n=300 \text { participants }
\end{gathered}
$$

To minimize the effect of no response in the survey, $10 \%$ of 300 , which is 30 persons were added to the calculated sample size. This gave to a total of 330 participants as the minimum sample size.

The study used structured questionnaire as the data collection instrument. The questionnaire which was designed by the researchers was divided into three key parts. The first part was used to collect basic information related to the professional background of the participants, while the second part covered questions on the participants' rating of the demerits of having urban greenbelts in their respective cities. The third part covered perception of the respondents on the role of urban greenbelts in environmental and to the socio-economic development of the cities as well as the ways for preserving them in Nigeria. The questions in the second and third parts of the questionnaire were based on findings from the literature relating the two contending views on urban greenbelt policy as previously highlighted in this paper. The questions were farmed around such issues as the incursion into green belts, development within green belt, influence of green belt on increasing cost of housing, location of housing beyond green belt boundaries. Others are preservation of green belts, the use Brown fields as alternative source of land for housing development, perception of green belt as local source of food, greenbelts as means of preserving agricultural land and as provider of habitats for endangered plants and animals. In collecting data on these, each of the participants was 
requested to rate the extent to which he/she agrees/disagrees with statements describing the demerits of having urban greenbelts; the role of the urban greenbelts in environmental and socio-economic development of the cities and ways for preserving the existing greenbelts. The scale of measurement used was a 4-point Likert type scale ranging from $1=$ strongly disagree to $4=$ strongly agree and $0=$ Not Sure.

The survey was conducted in the study area in 2019. This involved the administration and retrieval of hard copies of the pre-tested questionnaire to randomly selected participants in the study area. The researchers and research assistants recruited and trained for the research administered copies of the questionnaire to the participants by hand. A total of 340 copies of the questionnaire comprising 85 copies in each of the four cities selected for the study were given to the participants. Table 1 shows the number of questionnaires that were distributed and retrieved and the response rate. It can be seen that the response rate in the survey was high at $88.2 \%$ (Table 1 ). In addition, photographic materials were also used in the data collection process.

The data gathered via the questionnaire were analysed with the help of the Statistical Package for the Social Sciences (SPSS). In line with the stated research objectives the data were analysed using descriptive statistics such as frequency and percentage distributions as well as Chi-Square Tests. The results are presented using tables and charts as seen in the next section of the paper.

\section{Results}

\subsection{Respondents' View on the Demerits of Urban Greenbelts}

Before delving into the participants' views on the demerits of having urban greenbelts, it is important to describe briefly the participants in the survey. From the results, it was found that the participants comprised architects $57(19.0 \%)$, real estate developers $52(17.3 \%)$, engineers 51(17.0\%), land surveyors $51(15.0 \%)$, town planners, $45(15.0 \%)$ and quantity surveyors $44(14.7 .0 \%)$. The results also show that a majority $(76.3 \%)$ of the respondents were males, while less than one-third (23.7\%) were females. It is obvious from these results that the highest number of participants in the survey is architects, followed by real estate developers and engineers, respectively, while the least number are quantity surveyors. These results also indicate that a majority of the participants are males, which goes to suggest that the built environment professions and real estate development in this part of Nigeria are dominated by male practitioners.

Table 1. Percentage Response of the respondents

\begin{tabular}{|c|c|c|c|c|}
\hline City & $\begin{array}{c}\text { No of questionnaires } \\
\text { administered }\end{array}$ & $\begin{array}{c}\text { No of questionnaire } \\
\text { completely Successfully } \\
\text { filled }\end{array}$ & $\begin{array}{c}\text { No of questionnaire not } \\
\text { properly filled }\end{array}$ & $\begin{array}{c}\text { Response rate } \\
\text { in \% }\end{array}$ \\
\hline Owerri & 85 & 76 & 9 \\
\hline Abakaliki & 85 & 73 & 12 \\
\hline Enugu & 85 & 76 & 95.9 \\
\hline Awka & 85 & $\mathbf{3 0 0}$ & 10 \\
\hline Total & $\mathbf{3 4 0}$ & $\mathbf{3 0 0}$ & $\mathbf{4 0}$ \\
\hline
\end{tabular}


in Environmental and Socio-Economic Development of Urban Areas in Southeast Nigeria

Table 2. Participants' views on the demerits of urban greenbelt policy

\begin{tabular}{|c|c|c|}
\hline $\begin{array}{c}\text { Issues related to greenbelt } \\
\text { policy }\end{array}$ & Frequency & $\begin{array}{c}\text { Percentage } \\
(\%)\end{array}$ \\
\hline \multicolumn{3}{|l|}{$\begin{array}{c}\text { Green belt contributes to } \\
\text { increase in housing cost }\end{array}$} \\
\hline Strongly disagree & 46 & 15.3 \\
\hline Disagree & 179 & 59.7 \\
\hline Agree & 37 & 12.3 \\
\hline Strongly agree & - & - \\
\hline Undecided & 38 & 12.7 \\
\hline \multicolumn{3}{|l|}{$\begin{array}{c}\text { Green belts promotes housing } \\
\text { scarcity in the city }\end{array}$} \\
\hline Strongly disagree & 68 & 22.7 \\
\hline Disagree & 150 & 50.0 \\
\hline Agree & 33 & 11.0 \\
\hline Strongly agree & 10 & 3.3 \\
\hline Not sure & 39 & 13.0 \\
\hline \multicolumn{3}{|l|}{$\begin{array}{c}\text { Green belt result cramming of } \\
\text { housing development }\end{array}$} \\
\hline Strongly disagree & 47 & 15.7 \\
\hline Disagree & 156 & 52.0 \\
\hline Agree & 65 & 21.7 \\
\hline Strongly agree & - & - \\
\hline Not sure & 32 & 10.7 \\
\hline \multicolumn{3}{|l|}{$\begin{array}{c}\text { Green belt increase pressure } \\
\text { on the existing land }\end{array}$} \\
\hline Strongly disagree & 12 & 4.0 \\
\hline Disagree & 40 & 13.3 \\
\hline Agree & 141 & 47.0 \\
\hline Strongly agree & 85 & 28.3 \\
\hline Not sure & 22 & 7.3 \\
\hline
\end{tabular}

Regarding the participants' views on the demerits of having urban greenbelts, the results reveal that a majority $(75 \%)$ of the stakeholders sampled disagreed with the notion that urban greenbelt contributes to increasing cost of housing in their respective cities (Table 2). Similarly, most $(72.75 \%)$ of the respondents also disagreed with the view that greenbelts promote housing scarcity, and a high proportion $(73.7 \%)$ of the participants also felt that urban green belts do not result to the cramming of new housing developments in the study area. However, the results show that most $(75.3 \%)$ of the respondents agree that green belts contribute to increasing pressure on the existing land in cities sampled (see Table 2).

From the results in Table 2, it is obvious that on the one hand a majority of the professionals sampled in the study area have contrary views on the influence of greenbelts on increasing cost and scarcity of housing and cramming of new housing developments in the study area. On the other hand, most of them were in agreement that urban greenbelts can put pressure on the existing land in towns and cities in the study area.

\subsection{Role of Greenbelts in Urban Environment and to Socio-Economic Development}

Table 3 is a display of the results on the participants' rating of the role of greenbelts in environmental and socio-economic development of the urban areas sampled.

Table 3. Role of urban greenbelts in environment and socio-economic development

\begin{tabular}{|c|c|c|}
\hline $\begin{array}{c}\begin{array}{c}\text { Rating of the relevance of } \\
\text { greenbelt }\end{array} \\
\end{array}$ & Frequency & $\begin{array}{c}\text { Percentage } \\
(\%)\end{array}$ \\
\hline \multicolumn{3}{|l|}{$\begin{array}{c}\begin{array}{c}\text { Greenbelt as protector of air } \\
\text { and water }\end{array} \\
\end{array}$} \\
\hline Strongly disagree & 6 & 2.0 \\
\hline Disagree & - & - \\
\hline Agree & 120 & 40.0 \\
\hline Strongly agree & 174 & 58.0 \\
\hline Not sure & - & - \\
\hline \multicolumn{3}{|l|}{$\begin{array}{c}\text { Greenbelt as a local source of } \\
\text { food }\end{array}$} \\
\hline Strongly disagree & - & - \\
\hline Disagree & - & - \\
\hline Agree & 190 & 63.3 \\
\hline Strongly agree & 74 & 24.7 \\
\hline Not sure & 36 & 12.0 \\
\hline \multicolumn{3}{|l|}{$\begin{array}{c}\text { Greenbelt as means to } \\
\text { preserve agricultural land }\end{array}$} \\
\hline Strongly disagree & - & - \\
\hline Disagree & 6 & 2.0 \\
\hline Agree & 197 & 65.7 \\
\hline Strongly agree & 77 & 25.7 \\
\hline Not sure & 20 & 6.7 \\
\hline \multicolumn{3}{|l|}{$\begin{array}{c}\text { Greenbelt as provider of } \\
\text { habitats for engendered } \\
\text { species of plants and animals }\end{array}$} \\
\hline Strongly disagree & - & - \\
\hline Disagree & 6 & 2.0 \\
\hline Agree & 161 & 53.7 \\
\hline Strongly agree & 133 & 44.3 \\
\hline Not sure & - & - \\
\hline \multicolumn{3}{|l|}{$\begin{array}{c}\text { Greenbelt prevent urban land } \\
\text { degradation }\end{array}$} \\
\hline Strongly disagree & - & - \\
\hline Disagree & 99 & 33.0 \\
\hline Agree & 75 & 25.0 \\
\hline Strongly agree & 85 & 28.3 \\
\hline Not sure & 41 & 13.7 \\
\hline
\end{tabular}

From the results it can be seen that most $(98.0 \%, 88.0 \%$ and $91.4 \%$ ) of the respondents were in agreement that urban greenbelts protect air and water, are local sources of food and serve as a way to preserve agricultural land, respectively (Table 3 ). Similarly, a majority $(98.0 \%$ and $53.3 \%$ ) also agreed that urban greenbelts provide habitats for engendered species of plants and animals, and prevent urban land degradation, respectively. These results in Table 3 generally show that greenbelts play a significant role in environmental development of the cities sampled, especially as it relates to the preservation of air, water and land and promotion of biodiversity and in ensuring food security. The Chi-Square test of significance was 
conducted to examine the level of significance of the participants' ratings of the role of urban greenbelts in environmental and socio-economic development of cities in the study area. The results revealed that the participants' perception of this was statistically significant $\left(\mathrm{X}^{2}\right.$ $=142.798$; alpha-significance $=0.000$ at $\mathrm{P}<0.01$ ) (Table 4). This suggests that the result obtained did not come by chance.

Table 4. Chi-square Test of Significance

\begin{tabular}{|c|c|c|c|}
\hline & Value & df & $\begin{array}{c}\text { Asymptotic } \\
\text { Significance (2-sided) }\end{array}$ \\
\hline Pearson Chi-Square & $142.798^{\mathrm{a}}$ & 15 & 0.000 \\
\hline Likelihood Ratio & 182.750 & 15 & 0.000 \\
\hline $\begin{array}{c}\text { Linear-by-Linear } \\
\text { Association }\end{array}$ & 18.904 & 1 & 0.000 \\
\hline N of Valid Cases & 300 & & \\
\hline
\end{tabular}

\subsection{Strategies for Preserving Urban Greenbelts}

The participants were also requested to suggest ways for preserving urban greenbelts in the face of criticisms against them in the literature. Figure 4 shows the results of the distribution of the participants' according their agreement/disagreement against developments within urban green belt areas. From the results it is evident that whereas around $58.4 \%$ of participants did not support developments within urban greenbelts, about $33.3 \%$ were in support of developments within urban green belts (Figure 4). These results indicate that more than one-half of the built environment professionals sampled in this study do not agree with physical developments in greenbelts in the four cities investigated.

Again, Chi-Square test was used to investigate whether the participants' responses on developments on greenbelts were statistically significant or not. The results suggest that the perception of the respondents on this was statistically significant $\left(X^{2}=303.862\right.$; alpha-significance $=.000, \mathrm{P}<0.01)$ (Table 5). Again, this is an indication that the result did not come by chance.

Table 5. Chi-Square Test of Significance

\begin{tabular}{|c|c|c|c|}
\hline & Value & df & $\begin{array}{c}\text { Asymptotic } \\
\text { Significance } \\
\text { (2-sided) }\end{array}$ \\
\hline Pearson Chi-Square & $303.862^{\mathrm{a}}$ & 15 & 0.000 \\
\hline Likelihood Ratio & 341.610 & 15 & 0.000 \\
\hline $\begin{array}{c}\text { Linear-by-Linear } \\
\text { Association }\end{array}$ & 79.985 & 1 & 0.000 \\
\hline N of Valid Cases & 300 & & \\
\hline
\end{tabular}

In addition, around $71.0 \%$ of the participants also agreed that in preserving greenbelts, housing developments should be located beyond the boundaries of greenbelts in urban areas, while around $16.0 \%$ of them disagreed with this. Similarly, around $78.3 \%$ of the participants suggested that Brown fields should be used as alternative sources of land for housing development, while $21.7 \%$ of them disagreed with this view. Nonetheless, it was observed that almost all $(92.6 \%)$ of the respondents were of the view that in order to sustain greenbelts, they should be preserved and made to be permanent features in urban areas.

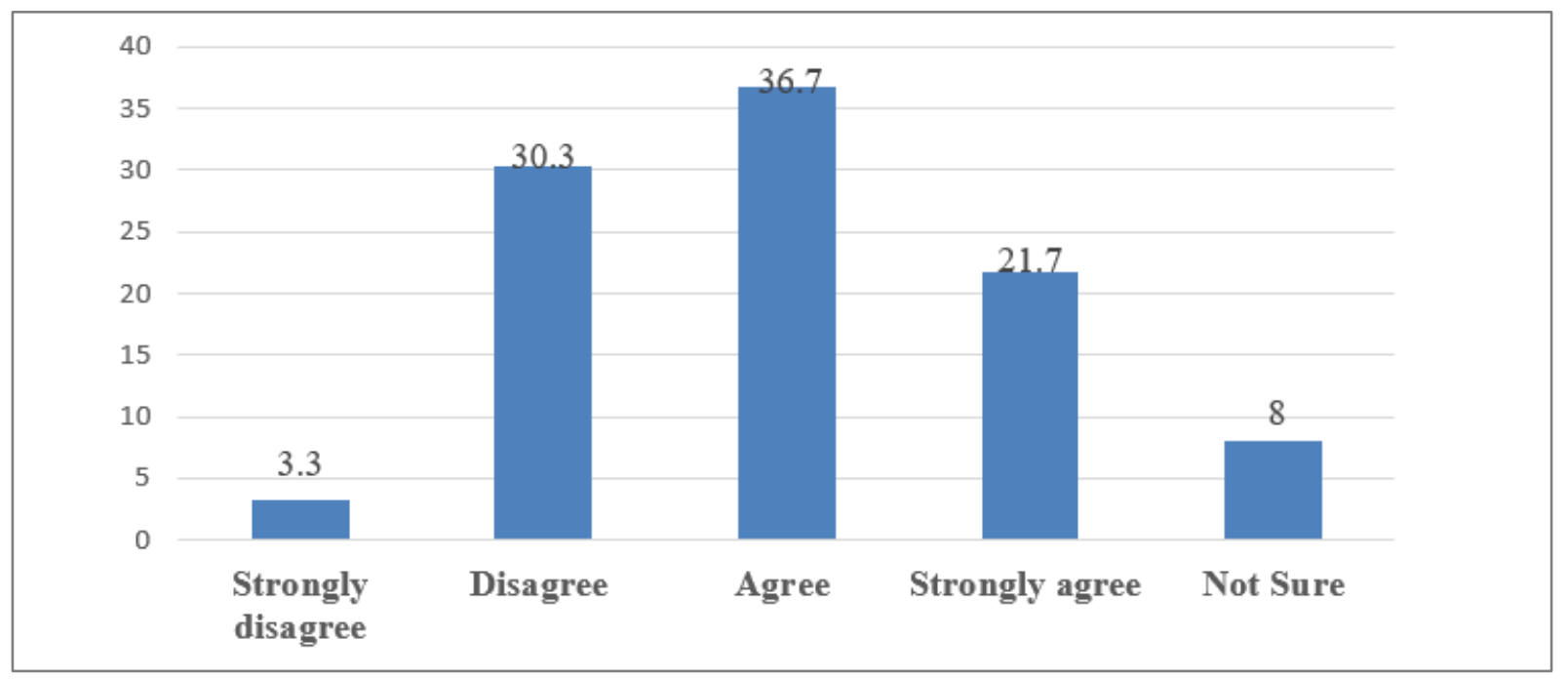

Figure 4. Respondents' views on development within Greenbelts 


\section{Discussion}

The purpose of this study was to investigate the demerits and roles of urban greenbelts in environmental and social-economic development of four selected cities in southeast Nigeria. From the findings presented in the previous section, three key issues have been brought up for discussion. First, the study revealed that a high majority of the built environment professionals and real estate developers sampled in the survey were not in support of the notion that green belts encouraged high density housing developments and contributed to the increasing cost and scarcity of housing in the study area. This appears to be contrary to the views by some authors on the impact of green belts on the cost of urban land and housing [see 29,37] and that incursion into green belts was necessary in gaining access to land for housing development; and thus helping to address scarcity of housing as also suggested by several authors [see for examples $3,4,49,58]$. What these mean is that most of the built environment professionals and real estate developers sampled in southeast Nigeria do not share the view that the existence of urban greenbelts is responsible for the scarcity and high cost of housing in the study area. They do not also believe that encroaching into green belts will provide the much needed land for housing required to address the existing housing supply deficit in these cities. However, they seem to be in support of Barker [31] that the designation of green belts needs to be reviewed in order to reduce the burgeoning pressure on land in these cities. In fact, Barker [31] had argued that greenbelts may lead to high density housing developments in cities, which according to Klimanova et al. [14] can make cities more vulnerable to challenges of climate change than low-density developments.

Second, it was also found that in support of previous studies, the participants in this research indicated that among other roles, urban green belts protect air and water provide habitats for engendered species of plants and animals and prevent urban land degradation and are local sources of food. These findings did not come as a surprise because previous studies have shown that the continuous expansion of urban areas into virgin and natural habitats poses significant environmental challenges associated with biodiversity loss [see 10, 22]. This is because greenbelts are known to provide natural habitats for different species of plants and animals within the urban ecosystem, which helps to enhance the adaptive capacity of cities to overcome climate change issues [13]. In addition, previous studies $[11,60]$ have also highlighted the negative influence of urban expansion on air quality, food production, soil conservation and water purification, while other studies [15,18-21] have shown that urban green belts protect air and water; and are also local sources of food $[25,55]$ as well as serve as means of conserving agricultural land [17,26,38,51]. What these mean is that on the one hand urban green belts play key roles in ensuring environment sustainability by promoting biodiversity, enhancing cities' capacity to cope with challenges associated with climate change through water and air purification and prevention of land degradation. These are no doubt consistent with the findings of a previous research on the role of urban green infrastructure in mitigating environmental sustainability challenges such as emission of greenhouse gases, poor waste management, and water pollution in Lagos southwest Nigeria [see 24]. On the other hand, urban greenbelts promote socio-economic development in ensuring food security as they are local sources food and medicinal plants, which are considered vital aspects of the sustainability development agenda.

Third, the results also revealed that nearly all the participants in the survey agreed that in view of the role of urban greenbelts in environmental and socio-economic development of the study area, they should be preserved and made to be permanent features in the contemporary cities. To achieve this, they opined that instead of encroaching into the existing greenbelts as sources of land for housing, new housing developments can be located beyond the boundaries of greenbelts and that Brown fields should also be considered as alternative sources of land for housing in the cities. These findings appear to be in agreement with the views expressed by other authors indicating greenbelts should be permanent features in urban areas [39] and that concerted efforts needed in preserving them [51]. They are also in line with view that having developments around the boundaries of greenbelts (where there exist) and relying on Brown fields as alternative sources of urban land for housing can help to conserve greenbelts in urban areas [15]. Notably, the idea of having physical developments beyond the boundaries of greenbelts can help in air pollution control and storm water runoff reduction, reduction in urban heat island $[18,19]$, enhancement of the aesthetics value of urban landscape, [37,52], provision of place for relaxation $[24,52]$, leisure and recreation activities within urban neighbourhoods [53]. Similarly, the suggestion on the use of Brownfields for housing development seems to have great potentials in the study area. This is because Ibem [61] reported that in many towns and cities in Nigeria, there are several abandoned industrial and office buildings and derelict sites that can be remodeled and developed to provide housing for the teeming urban population, which can contribute to resolving the present urban housing crisis in this country.

\section{Conclusions and Recommendations}

This study investigated the demerits and roles of urban greenbelts in environmental and socio-economic development of four selected cities in southeast Nigeria 
using the data derived from a survey of built environment professionals and real estate developers in the study area. From the findings, the following conclusions and recommendations have emerged. First is that most of the participants in the survey felt that the main demerit of greenbelts in the study area is that they contribute to increasing pressure on the existing urban land. This can in turn lead to scarcity of land for housing and high-density housing developments with their attendant consequences on the environmental, social and economic fabrics of cities and their inhabitants. In view of this, it is suggested that city planners and mangers should endeavour to establish land bank for housing and physical infrastructure development instead of encroaching on the existing greenbelts in urban areas.

Second, it can be concluded that urban greenbelts play key roles in environmental sustainability agenda in promoting biodiversity, conserving soil, purifying water and air and preventing land degradation; and are also relevant in socio-economic development of the cities by promoting food security, health and well-being of the population. These mean that urban green belts are essential components of sustainability agenda; and thus, development within or actions that seek to deplete them should be prohibited. In view of this, it is suggested that the existing laws that seek to ensure adequate preservation and protection of greenbelts in towns and cities in Nigeria should be strictly enforced and offenders made to face the full weight of the law. To achieve this, the relevant government agencies charged with the task of monitoring physical developments should be adequately equipped to discharge their duties. They can partner private sector organizations and professional bodies in the built environment to ensure effectiveness and efficiency in this task.

Third, it can be concluded that the strategies for preserving urban greenbelts include prohibition of physical development in the existing greenbelts; location of new housing developments beyond the boundaries of green belts and the use Brown fields as alternative sources of land for urban housing. This implies that green belts should be seen as permanent features; and thus limited incursion into them would only be allowed if only there are no alternatives. Based on this, it is recommended that Brown fields such as abandoned industrial and office buildings and derelict sites should be considered as alternative sources of land for urban housing development. Furthermore, it is also suggested that the notion that greenbelts in cities are of no economic value and thus should be used for housing development should be discarded because the environmental, social and economic benefits of urban greenbelts are enormous and should not be compromised. In view of this, the existing pieces of legislation and policies that seek to protect and preserve green belts should be further strengthened to make them more effective and relevant to current challenges associated with the existence of urban greenbelts in the study area in particular and Nigeria as a whole. It is also suggested that there is a need to review the existing development plans, while fresh ones should pay adequate attention to the protection of green belts. Moreover, integrated development plans for towns, cities and regions should make adequate provision for greenbelts with workable strategies for protecting and preserving them by urban land speculators.

Although this research can be seen as having achieved its goals, it has some deficiencies that are usually associated with surveys of this nature. Notably, the study is limited as the sampled population comprised mainly professionals in the built environment and estate developers in four selected cities in southeast Nigeria. This implies that the findings are based on the biases of these occupational groups sampled in the four cities and cannot be extended to other professional groups such as sociologists, economists, lawyers as well as residents of the selected cities in the study area. Therefore, further research is required to include other stakeholders and more cities in the study area for more robust results that can be generalized for urban areas in the southeast zone of Nigeria.

\section{REFERENCES}

[1] National Population Commission. "Nigerian Population Census 2006-Analysis of Gender and Sustainable Development". Abuja. 2006.

[2] National Bureau of Statistics (NBS) "Annual Abstract Statistics. National Bureau of Statistics". Abuja.2006.

[3] Egunjobi, L. Onakomaiya, S.O. and Oyesiku, O.O. "Planning the Nigerian Cities for Better Quality of Life". Environment, Physical Planning and Development in Nigeria, Department of Geography and Regional Planning, Olabisi Onabanjo University, Ago-Iwoye, Nigeria, Pp. 89-107. 2002.

[4] Olarenwaju D.O. "Town Playing- A Veritable Means for Poverty Reduction". Federal University of Technology, Akure, 26th October 2004. Volume 38 of Inaugural lecture series, Publication Committee, FUTA, pp.1-39.2004.

[5] Daramola, S.A. and Ibem, E.O. "Urban Environmental Problems in Nigeria, Implications for Sustainable Development". Journal of Sustainable Development in Africa, Vol.12, No.1, pp.124-145, 2010.

[6] Gospodini, A. and Manika, S. "Conceptualising Smart and Green Public Open Spaces: Investigating Redesign Patterns for Greek Cities". Civil Engineering and Architecture, 8(3), 371-378, 2020. (https://doi.org/10.13189/cea.2020.080322).

[7] Cities Alliance Foundation for Urban Development in Africa. "The Legacy of Akin Mabogunje, Cities Alliance", Washington, D.C. 2006

[8] Alabi, M. O. "A study of the physical expansion of Lokoja 
Town, Using geo-information Techniques". Confluence Journal of Environmental Studies, Vol.2, No.1 pp. 48-52, 2007.

[9] Irwin, E. G. and Bockstael, N. E. "The Evolution of Urban Sprawl. Evidence of Spatial Heterogeneity and Increasing Land Fragmentation”. PNAS Journal, Vol. 104, N0. 52, pp. 20672-20677, 2007. (https://doi.org/10.1073/pnas.0705527 105)

[10] Haase, D., Larondelle, N. and Anderson, E. “A Quantitative Review of Urban Ecosystem Service: Assessment, Concepts, Models, and Implementations". Ambio, Vol.43, pp.413-433, 2014. (doi: 10.1007/s13280-014-0504-0)

[11] Xie, W. Huang, Q. He, C. and Zhao, X. "Projecting the Impacts of Urban Expansion on Simultaneous Losses of Ecosystem Services, A case Study in Beijing, China". Ecological Indicators, Vol.84, pp.183-193, 2018.

[12] Zhang, D., Huang, Q., He, C. and Wu, J. "Impacts of Urban Expansion on Ecosystem Services in the Beijing- TianjinHebei Urban Agglomeration, China: A scenario analysis based on the Shared Socioeconomic Pathways". Journal of Resources, Conservation \& Recycling Vol. 125, pp.115-130, 2017. (https://doi.org/10.1016/j.resconrec.2017.06.003)

[13] De Carvalho R. M. "Impacts of Urbanization on Green Infrastructure Ecosystem Services. The Case Study of PostSoviet Moscow". 2018. Retrieved on April 29, 2012 from www.researchgate.net > publication > 330583320 .

[14] Klimanova, O.K., Eugeny, K. and Illarionova, O. "Impacts of Urbanization on Green Infrastructure. Ecosystem Services: The Case Study of Post-Soviet Moscow”. Belgium Journal of Geography, Vol.4, pp.1-15, 2018. (https://doi.org/10.4000/belgeo.30889)

[15] Royal Town Planning Institute (RTPI) "Published a Statement on Modernizing Green Belts". RTPI Vol.19, pp. 302- 315, 2002.

[16] Gunn, S. "Green Belts, A Review of the Regions Responses to a Changing Housing Agenda". Journal of Environmental Planning and Management, Vol. 50, No. 5, pp. 595-616, 2006. (https://doi.org/10.1080/09640560701475154).

[17] Bengston, D. N. and Youn. "Urban Containment Policies and the Protection of Natural Areas, The Case of Seoul's Greenbelt". Ecology and Society, Vol. 11, No.1, pp.3-23, 2006.

[18] Baro, F. Chaparro, E. Gómez-Baggethun, J. J. and Langemeyer, D.J. "Contribution of Ecosystem Services to Air Quality and Climate Change Mitigation Policies, The Case of Urban Forests in Barcelona, Spain”. Ambio, Vol. 43, pp. 466-479, 2014. (doi: 10.1007/s13280-014-0507-x).

[19] Inkiläinen, E.N.M, McHale, M.R., Blank G.B., James, A.L and Nikinmaa, E. "The Role of the Residential Urban Fore in Regulating through Fall: A Case Study in Raleigh, North Carolina, USA". Landscape and Urban Planning, Vol. 119, pp. 91-103, 2013. (https://doi.org/10.1016/j.landurbplan.20 13.07.002)

[20] Akbari, H. "Shade Trees Reduce Building Energy Use and CO2 Emissions from Power Plants'. Environmental Pollution, Vol. 116. (Suppl, S), pp.119-26, 2002. (https://doi.org/10.1016/S0269-7491(01)00264-0).

[21] Sawka, M. Millward, A., McKay, J, Sarkovich, M.
"Growing Summer Energy Conservation through Residential Tree Planting". Landscape and Urban Planning, Vol. 113, pp.1-9, 2013. (https://doi.org/10.1016/j.landurbpl an.2013.01.006).

[22] Burkhard, B., I. Petrosillo, and R. Constanza. "Ecosystem services: Bridging Ecology, Economy and Social sciences". Ecological Complexity, Vol. 7, pp. 257-259, 2010.

[23] Nowak, D. J. Hirabayashi, S. Bodine, A.and Greenfield, E. "Tree and forest effects on air Quality and Human Health in the United States". Journal of Environmental Pollution, Vol. 193, pp.119-129, 2014. (http//doi. org/10.1016/j.envpol.20 14.05.028).

[24] Dipeolu, A. A, and Ibem, E.O. “Green Infrastructure Quality and Environmental Sustainability in Residential Neighbourhoods in Lagos, Nigeria". International Journal of Urban Sustainable Development, Vol. 12, No. 3, pp. 267282, 2020. (https,//doi.org/10.1080/19463138.2020.171950 $0)$.

[25] Adeyemi, A. A. Ohwo, O. A. and Ekeada, I.S. "Status and Distribution Patterns of Selected Medicinal and Food Tree Species in Owerri West Local Government Area of Imo State, Nigeria". Journal of Agriculture, Forestry and the Social Sciences, Vol.13, No 1, pp. 44-62, 2015.

[26] Abdulkarim, M. "Revitalizing Urban Public Open Spaces, Through, Vegetative Enclaves in Lokoja, Nigeria". Journal of the Nigerian Institute of Architects. Vol. 4, No. 1, pp. 10-20, 2004.

[27] Ladan, S.I. "Halting the Disappearance of Green belts for Sustainable Development in Urban Centers of Nigeria". Conference Paper, the 59th Annual Conference of Association of University of Ibadan, Oyo State, Nigeria, 2018.

[28] Christian Voice Online CVO. "Imo Government Pays N30million Compensation for Demolished Houses".2012. Available at www.christainvoicenewsonline.com (19th August, 2017).

[29] Ali, A. K. "Greenbelts to contain urban growth in Ontario, Canada, Promises and Prospects". Planning Practice and Research, Vol. 23, No. 4, pp. 533-548, 2008.(https://doi.org/10.1080/02697450802522889).

[30] Amati, M. and Taylor, L. "From Green Belts to Green Infrastructure". Journal of Planning, Practice \& Research, Vol.25, No. 2, pp. 143-155, 2010.(https://doi.org/10.1080/0 2697451003740122).

[31] Baker, K. "Review of Land-Use Planning, Final Report-Recommendations”. London, HM Treasury, 2006.

[32] Margules, C. R. and Pressey, R. H. "Systematic Conservation Planning". Nature, Vol. 405, pp.243- 253, 2000. (https://doi.org/10.1038/35012251).

[33] Sanderson, E.W., Walston J., \& Robinson J.G. "From Bottleneck to Breakthrough, Urbanization and the Future of Biodiversity Conservation". Bioscience, Vol. 68, No.6, pp.412-426, 2018. ( doi: 10.1093/biosci/biy039)

[34] Esspee, O. "Threat Factors among Birds in Nigeria". Love Press, Lagos, 2006.

[35] Amati, M. "Green Belts. A Twentieth-Century Planning Experiment". In Urban Green Belts in the Twenty-First 
Century, Edited by Amati, M. Ashgate, Hampshire, UK. Pp 1-18, 2008.

[36] Ofomata, G.E.K. "Relief Drainage and Landform in Ofomata G.E.F (ed). Survey of Igbo Nation". African First Publishers Limited, Owerri. Pp 83-98, 2002.

[37] Amati, M. \& Yokohari, M. "The Establishment of the London Greenbelt, Reaching Consensus Over Purchasing Land”. Journal of Planning History, Vol.6, No.4, pp.311-337, 2007.( https://doi.org/10.1177/1538513207302695)

[38] Freestone, R. “Greenbelts in City and regional planning”. In K. Parsons \& D. Schuyler (Eds). From Garden City to Green City, The Legacy of Ebenezer Howard, Baltimore. Pp. 67-98, 2002.

[39] Kuhn, M. and Gailing, L. "From Green belt to Regional Parks, History and Challenges of Suburban Landscape Planning in Berlin". In M Amati (Ed) Urban Green belt in the Twenty First Century, London, Ashgate, Pp. 185202,2008 .

[40] Kim, J. and Kim, T.K. "Issues with green belt reform in the Seoul Metropolitan Area", In M. Amati (Ed.) Urban Green Belts in the Twenty first Century, London, Ashgate, Pp. 37-59, 2008.

[41] Watanabe, T., Amati, E., K. and Yokohari, M. "The Abandonment of Tokyo's Green belt and the Search for a New Discourse of Preservation in Tokyo's Suburbs". Urban Green belt in the Twenty First Century. Ashgate, London, Pp.21- 37, 2008.

[42] Dipeolu, A. A., Ibem, E.O. and Fadamiro, J.A. "Influence of Green Infrastructure on Sense of Community in Residents of Lagos Metropolis, Nigeria". Journal of Human Behavior in the Social Environment, 30(6),743-759, 2020. (https,//doi.org/10.1080/10911359.2020.1740853).

[43] Pembrokeshire County Council Development and Rights of Way Committee. "Pembrokeshire County Council Development and Rights of Way Committee Statement to Application 07/1581/PA, Lammas Low Impact Initiatives Limited". 2010. Retrieved on 11 September 2010 from available at www.lammas.org.uk.

[44] Vernet, N and Coste, A. "Garden Cities of the 21st Century, A Sustainable Path to Suburban Reform" Urban Planning Journal, Vol. 2, No.4, pp. 45-60, 2017. (doi: 10.17645/up.v2i4.1104).

[45] Hall, P. "Cities of Tomorrow”. London, Blackwell, 2002.

[46] Konijnendijk, C. "Danish Centre for Forest, Landscape and Planning Faculty of Life Sciences". University of Copenhagen Rolighedsve, Frederiksberg, Denmark, 2010.

[47] Ståhle, A. and Caballero, L. "Greening metropolitan Growth. Integrating Nature Recreation, Compactness and Spaciousness in Regional Development Planning". International Journal of Urban Sustainable Development, Vol. 2, No. 1-2, pp. 84-98, 2010.

[48] Falade, J.B. "Public Acquisition of Land for Landscaping and Open Space". Management Journal of Nigeria Institute of Town Planners, Vol.11, pp. 20-43,1998.
[49] Ladan S.I. "Achieving Effective Vegetation Cover in Katsina Urban Area, Katsina State. Global Journal of Science Frontier Research Environmental and Earth Science, Vol.14, No. 1, pp. 8-22, 2014.

[50] Watanabe, T., Amati, E., K. and Yokohari, M. "The Abandonment of Tokyo's Green belt and the Search for a New Discourse of Preservation in Tokyo's Suburbs". Urban Green belt in the Twenty First Century. Ashgate, London, Pp.21- 37, 2008.

[51] Abbot, R. "Planning a Sustainable City. The Growth Boundary. In Urban Sprawl, Causes, Consequences and Policy Responses". The Urban Institute Press, Washington D.C., pp.207-235, 2002.

[52] Chaudhary, P. Bagra, K. and Singh. H. "Urban Greenery Status of Some Indian Cities-A Short Communication". International Journal Environmental Science and Development, Vol. 2, No. 2, pp. 10-12, 2011.

[53] Ezeamaka, C.K. and Oluwole, O.A. "Assessment of Recreational Facilities in Federal Capital City, Abuja, Nigeria". Indonesian Journal of Geography, Vol.48, No.1, pp.21-27, 2016. (https://doi.org/10.22146/ijg.12498).

[54] Xie, X., Kang, H., Behnisch, M., Baildon, M. and Krüger, T. "To What Extent Can the Green Belts Prevent Urban Sprawl? A Comparative Study of Frankfurt am Main, London and Seoul". Sustainability, Vol.12, No. 2, pp. 2-13, 2020. (https,//doi.org/10.3390/su12020679).

[55] Faysal, R. Carbon in the Bank- Ontario Greenbelt and its Role in the Mitigating Climate Change, David Suzuki Foundation, 2008. Retrieved on May 62016 from www.davidsuzuki.org.

[56] Adeyemi, A. Botai, J. Ramoelo, A. Van der Merwe, F. and Tsela, P. "Effect of Impervious Surface Area and Vegetation Changes on Mean Surface Temperature over Tshwane Metropolis, Gauteng Province, South Africa". South African Journal of Geomatics, Vol. 4, No. 4, pp. 351-368, 2015.(doi: 10.4314/sajg.v4i4.1).

[57] Sawka, M. Millward, A., McKay, J. and Sarkovich, M. "Growing Summer Energy Conservation through Residential Tree Planting". Landscape and Urban Planning, 113, 1-9, 2013. (https://doi.org/10.1016/j.landurbplan.2013. 01.006).

[58] Brack, C.L. Pollution Mitigation and Carbon Sequestration by an urban forest. Environmental Pollution, Vol. 116, pp. 195-200. 2002. (https://doi.org/10.1016/S0269-7491(01)00 251-2).

[59] Yamane, T. "Elementary Sampling Theory". Prentice-Hall, Englewood Cliffs, New Jersey, 1967.

[60] Zhang, D., Huang, Q., He, C. and Wu, J. "Impacts of Urban Expansion on Ecosystem Services in the Beijing-TianjinHebei Urban Agglomeration, China”. Journal of Resources, Conservation \& Recycling, Vol. 125, pp.115-130,2017. (https://doi.org/10.1016/j.resconrec.2017.06.003).

[61] Ibem, E. O. "Bad Memories and Good Prospects for Housing. Led Urban Regeneration Projects in Nigeria" in Leary, M.E. and McCarthy, J. (eds.) Companion to Urban Regeneration. London. Routledge, pp 341-350, 2013. 